PREPARED FOR THE U.S. DEPARTMENT OF ENERGY, UNDER CONTRACT DE-AC02-76CH03073

PPPL-3658

PPPL-3658

UC-70

The NSTX Trouble Reporting System

by

S. Sengupta and G. Oliaro

January 2002

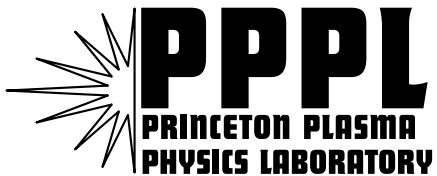

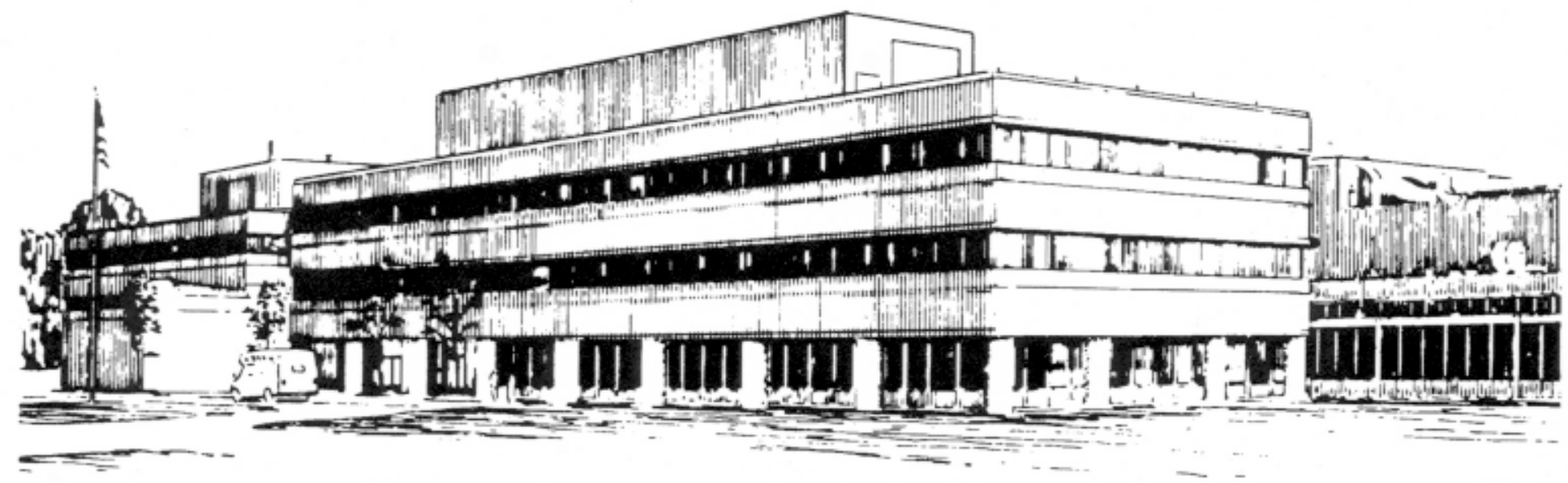

PRINCETON PLASMA PHYSICS LABORATORY PRINCETON UNIVERSITY, PRINCETON, NEW JERSEY 


\section{PPPL Reports Disclaimer}

This report was prepared as an account of work sponsored by an agency of the United States Government. Neither the United States Government nor any agency thereof, nor any of their employees, makes any warranty, express or implied, or assumes any legal liability or responsibility for the accuracy, completeness, or usefulness of any information, apparatus, product, or process disclosed, or represents that its use would not infringe privately owned rights. Reference herein to any specific commercial product, process, or service by trade name, trademark, manufacturer, or otherwise, does not necessarily constitute or imply its endorsement, recommendation, or favoring by the United States Government or any agency thereof. The views and opinions of authors expressed herein do not necessarily state or reflect those of the United States Government or any agency thereof.

\section{Availability}

This report is posted on the U.S. Department of Energy's Princeton Plasma Physics Laboratory Publications and Reports web site in Fiscal Year 2002. The home page for PPPL Reports and Publications is: http://www.pppl.gov/pub_report/

DOE and DOE Contractors can obtain copies of this report from:

U.S. Department of Energy

Office of Scientific and Technical Information

DOE Technical Information Services (DTIS)

P.O. Box 62

Oak Ridge, TN 37831

Telephone: (865) 576-8401

Fax: (865) 576-5728

Email: reports@adonis.osti.gov

This report is available to the general public from:

National Technical Information Service

U.S. Department of Commerce

5285 Port Royal Road

Springfield, VA 22161

Telephone: 1-800-553-6847 or

(703) 605-6000

Fax: (703) 321-8547

Internet: http://www.ntis.gov/ordering.htm 


\title{
The NSTX Trouble Reporting System
}

\author{
S.Sengupta, G. Oliaro, Princeton Plasma Physics Laboratory, P.O. Box 451, Princeton, New Jersey, \\ 08543
}

\begin{abstract}
An online Trouble Reporting System (TRS) has been introduced at NSTX. The TRS is used by NSTX operators to report problems that affect NSTX operations. The purpose of the TRS is to enhance NSTX reliability and maintainability by identifying components, occurrences, and trends that contribute to machine downtime. All NSTX personnel have access to the TRS. The user interface is via a web browser, such as Netscape or Internet Explorer. This web-based feature permits any $\mathrm{X}$ terminal, PC, or MAC access to the TRS. The TRS is based upon a trouble reporting system developed at the DIII-D Tokamak, at General Atomics Technologies [1]. This paper will provide a detailed description of the TRS software architecture, user interface, MS SQL server interface and operational experiences. In addition, sample data from the TRS database will be summarized and presented.
\end{abstract}

\section{INTRODUCTION}

Prior to TRS system, all NSTX Trouble reports were maintained manually by individual groups. The trouble report system typically consisted of a $\log$ book into which problem were recorded. The proper responsible person (RP) was then notified for repair. This system did not provide for the solution of the problem to be recorded for future reference. Under new TRS system all trouble reports are entered into a single database with a unique trouble report number (TrNo). The database includes elements such as the major system group, subsystem group, description of problems, and a time stamp and a description of repair done on TrNo by the RP. The NSTX Chief Operating Engineer (COE) will closeout the TrNo when the problem has been resolved satisfactorily. Much time and effort has been invested in the careful design, development and maintenance of this custom web based system in order to provide physicists and engineers at NSTX with the most reliable and user friendly systems to report NSTX problems.

\section{TROUBLE REPORT SYSTEMS OVERVIEW}

The TRS system objective is to make data entry 'user friendly'. Data validation is performed whenever a new Trouble Report is entered into the database or a record is updated. The process of using the NSTX Trouble Report system is shown in fig 1 .

1. The Trouble Report originator submits a new Trouble Report via "Add NSTX Trouble Report" input form. The first field the originator selects is a system Group and SubGroup from a drop-down menu box. Each trouble report is classified according to the major system.

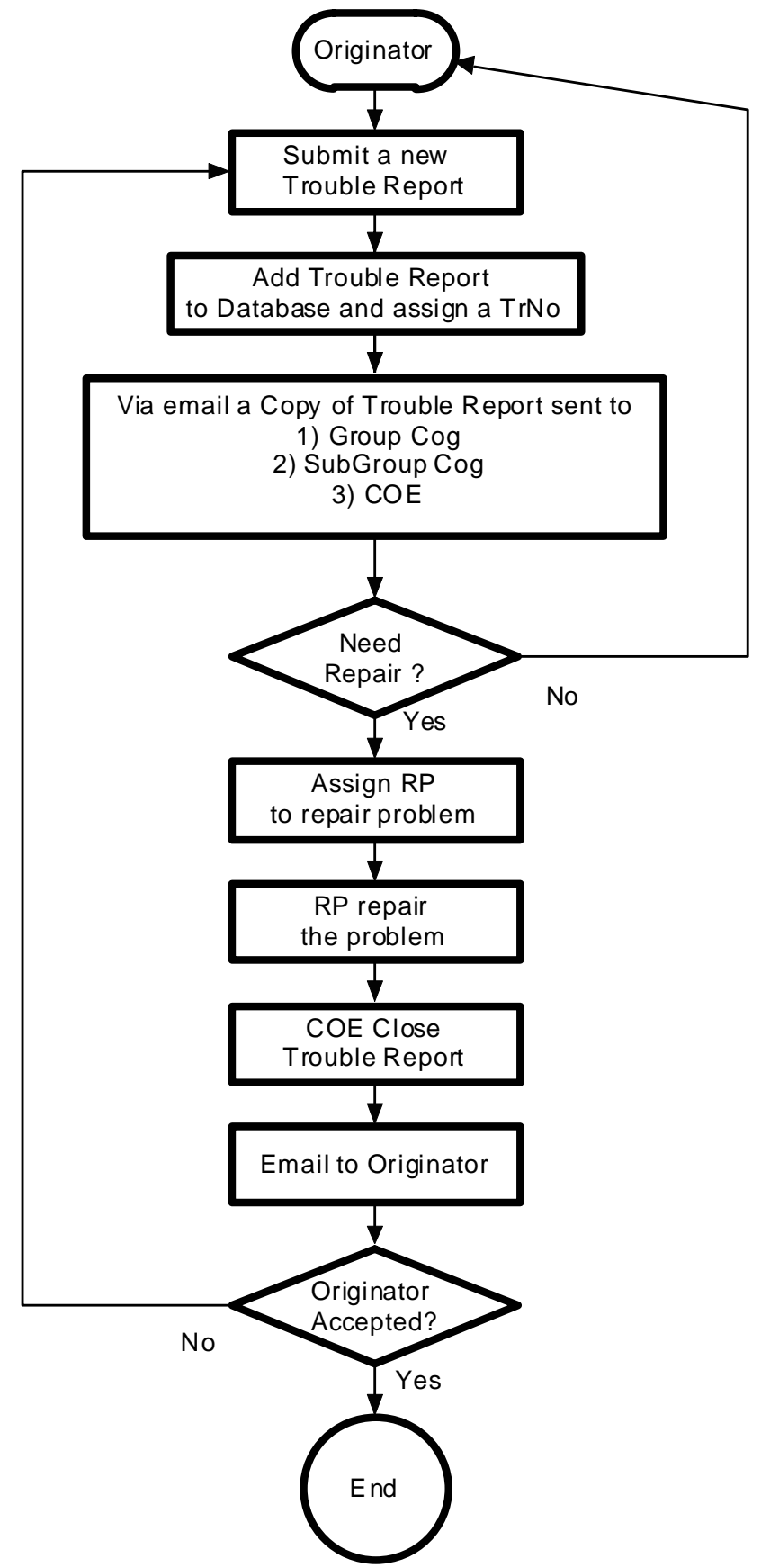

Fig 1 : NSTX Trouble Report Flow Diagram 
(Groups) and subsystem (Subgroups) of each engineering subsystem at NSTX. The NSTX trouble report system is currently organized into eight (8) Groups and fifty four (54) SubGroups. Samples of Groups and their SubGroups are shown below:

Group

Auxiliary Systems

\section{SubGroup}

- Bakeout

Gas Delivery System

GDC

Vacuum

Water

Other

$\mathrm{CI} \& \mathrm{C}$

- CAMAC Modules

Data Acquisition

EPICS

Facility Clock

HIS

PCs

Xterms

Other

Next, the originator enters a brief description of the problem into a text-area field. The Magnitude and Cause of the Problem are selected from fixed list box, and finally, the originator selects their name from a valid list of users, and submit the trouble report.

2. A unique Trouble Report number (TrNo) is automatically assigned and the TRS program sends email to Group Cog, Subgroup Cog and COE.

3. The responsible person (RP) will use the TRS to respond to the trouble report. When the problem has been fixed, or an estimated time of repair has been determined, then the "Respond to Trouble Report" form is used. The RP will provide the brief description of repair and the actual or estimated repair date.

4. The COE is responsible for keeping track of all open Trouble Reports. When a Trouble Report is satisfactorily repaired the COE closes it. Whenever a Trouble Report is closed, the TRS program sends an email to the trouble report originator that the $\operatorname{TrNo}$ is closed along with the description of the repair. If the trouble report originator is not satisfied with the repair, originator can resubmit the trouble report. Also, the COE can reject a Trouble Report by deleting it if the COE thinks it was filed in error. If a trouble report repair is not done in a specific time period, the COE can send a reminder to the SubGroup Cog.

The NSTX TRS has extensive search capabilities to review any group of records or a particular TrNo. The following search criteria are available:

- Review Trouble Reports by Group

- Review Trouble Reports by Group and SubGroup

- Review Trouble Report by Trouble Report Originator

- Review Trouble Report by a TrNo

- Review all open Trouble Reports
- Review Trouble Report database structures such as User Names, Group names, SubGroup names, and View all Trouble Report

- Scroll individual Trouble Reports by Group and SubGroup

\section{DATABASES}

The Trouble Report database was originally created on a Microsoft Access 2000 Database and later converted to MS SQL Server 2000 database to maintain compatibility with existing PPPL databases. Access database lacks the performance and stability of a SQL server database.

Four related tables are maintained in SQL Server database. The following three tables have a fixed number of records and require few changes:

1. User Names Table contains the following fields: User Name, unique email address.

2. Group Table contains the following fields: System Group Name, Group Cog email address.

3. SubGroup Table has the following fields: System Group Name, SubGroup Name and SubGroup Cog email address.

The fourth table contains the actual trouble report information.

4. TR Table has the following fields: TrNo, TrStatus, TrDate, TrTime, Group, SubGroup, Originator Email, Problem Description, Magnitude of Problem, Cause of the Problem, RP Email, Repair Description, Repair completion date and TrNo close date.

All personnel at PPPL have access to TRS system for review purposes and only those whose names are in the User Names table have access to submit a trouble report. The COE has a protected password to perform his duties. The COE performs the following database maintenance duties:

- $\quad$ Add New User Names

- Modify or delete User Name

- Send Reminder to RP for not responding to a Trouble Report.

- Add/delete new Group and SubGroups

\section{WEB SERVER AND SQL QUERY}

The Web Server is the software component that reacts to and interfaces with Web browser/client. It has no ability to create or update Web Pages. Microsoft IIS 5.0 Web Server software used for this purpose. Microsoft FrontPage 2000 was used to generate all HTML and ASP code for TRS software package. Fig 2 displays the normal Web database process flow. This process is described below.

\footnotetext{
* Work performed under the auspices of the USDOE by Princeton Plasma Physics Laboratory under Contract No. DE-AC02-76CH03073.
} 


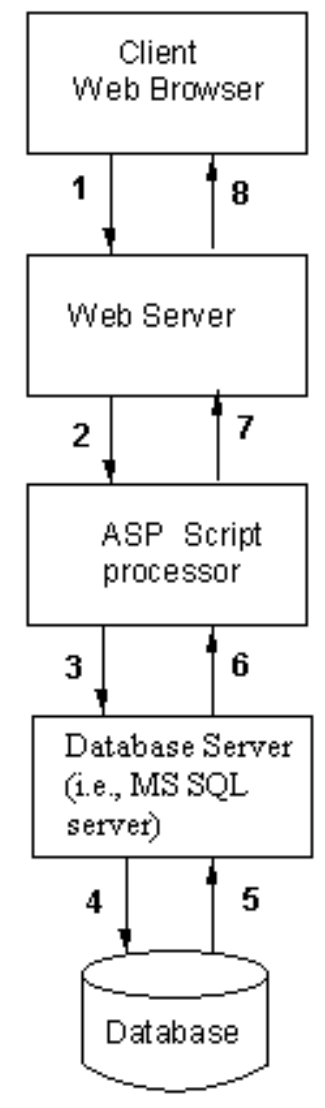

Fig 2 Web Database page process flow

Step 1: Client via HTML code initiates the process by submitting an ASP request to the web server.

Step 2: Web Server receives the ASP request and passes data to ASP script processor.

Step 3: The ASP script processor reads the requested page and executes any server-side script code.

Step 4: The MS SQL Server accesses the data via the ODBC connection to database. The role of the SQL Server is to sit between the Web Server and database. It is responsible for maintaining an open connection between Web Server and the Database Server at all times.

Step 5: The database sends results to the Database Server.

Step 6: The ASP Script processor receives data from Database Server.

Step 7: The ASP page responds to the client by sending a customized Web page to Web Server.

Step 8: Web Browser receives HTML sent to it from Web server and formats and displays data received.

\section{OPERATIONAL EXPERIENCE}

The TRS program was started in April 2001. During the period April through July, 46 trouble reports have been written by 10 reporters. The number of trouble reports in database is too small at this time to be useful in identifying components and trends that contribute to machine downtime.

\begin{tabular}{|l|c|c|}
\hline Group & $\begin{array}{l}\text { Number of } \\
\text { Trouble Reports }\end{array}$ & $\begin{array}{l}\text { *Sum of } \\
\text { Downtime }\end{array}$ \\
\hline Auxiliary Systems & 2 & 0 \\
\hline CIC & 15 & 0 \\
\hline Diagnostic Systems & 1 & 0 \\
\hline Facilities & 0 & 0 \\
\hline FCPC & 19 & 0 \\
\hline $\begin{array}{l}\text { Heating \& Current } \\
\text { Drive Systems }\end{array}$ & 0 & 0 \\
\hline Power Systems & 6 & 0 \\
\hline Torus Systems & 1 & 0 \\
\hline
\end{tabular}

* This data not in use.

\section{ENHANCEMENT TO D-III TRS}

The TRS that was originally furnished by General Atomics Technologies. This software was enhanced for use on NSTX. To achieve a faster access and reliable system TRS database was changed from Access 2000 database to MS SQL Server 2000. The TRS system GUI has been significantly enhanced, and include search facilities to identify status of a trouble report.

\section{FUTURE PLANS}

Upgrades for the TRS systems on NSTX may include:

1. Add another level called component group to SubGroup to identify problem by component level.

\section{CONCLUSION}

The TRS system provides NSTX with an automated trouble reports collection system, which can be used by the PPPL staff. At any time, the current status of a trouble report can be easily determined by opening several high level review pages. The accuracy of data is insured by extensive input data validity checking. The system uses current web and database tools and can be easily modified. The TRS system will allow engineers and scientists to consult previous repair history to better diagnose current operating problems.

\section{REFERENCE}

[1] P. I. Petersen and S.M. Miller , "The DIII-D Tokamak Trouble Report Database," in Proc. $14^{\text {th }}$ Symp. on Fusion gineering, p.776, 1991. 


\section{External Distribution}

Plasma Research Laboratory, Australian National University, Australia

Professor I.R. J ones, Flinders University, Australia

Professor J oão Canalle, Instituto de Fisica DEQ/IF - UERJ , Brazil

Mr. Gerson O. Ludwig, Instituto Nacional de Pesquisas, Brazil

Dr. P.H. Sakanaka, Instituto Fisica, Brazil

The Librarian, Culham Laboratory, England

Library, R61, Rutherford Appleton Laboratory, England

Mrs. S.A. Hutchinson, JET Library, England

Professor M.N. Bussac, Ecole Polytechnique, France

Librarian, Max-Planck-Institut für Plasmaphysik, Germany

J olan Moldvai, Reports Library, MTA KFKI-ATKI, Hungary

Dr. P. Kaw, Institute for Plasma Research, India

Ms. P.J . Pathak, Librarian, Insitute for Plasma Research, India

Ms. Clelia De Palo, Associazione EURATOM-ENEA, I taly

Dr. G. Grosso, Instituto di Fisica del Plasma, Italy

Librarian, Naka Fusion Research Establishment, J AERI, J apan

Library, Plasma Physics Laboratory, Kyoto University, J apan

Research Information Center, National Institute for Fusion Science, J apan

Dr. O. Mitarai, Kyushu Tokai University, J apan

Library, Academia Sinica, Institute of Plasma Physics, People's Republic of China

Shih-Tung Tsai, Institute of Physics, Chinese Academy of Sciences, People's Republic of China

Dr. S. Mirnov, TRINITI, Troitsk, Russian Federation, Russia

Dr. V.S. Strelkov, Kurchatov Institute, Russian Federation, Russia

Professor Peter Lukac, Katedra Fyziky Plazmy MFF UK, Mlynska dolina F-2, Komenskeho Univerzita, SK-842 15 Bratislava, Slovakia

Dr. G.S. Lee, Korea Basic Science Institute, South Korea

Mr. Dennis Bruggink, Fusion Library, University of Wisconsin, USA

Institute for Plasma Research, University of Maryland, USA

Librarian, Fusion Energy Division, Oak Ridge National Laboratory, USA

Librarian, Institute of Fusion Studies, University of Texas, USA

Librarian, Magnetic Fusion Program, Lawrence Livermore National Laboratory, USA

Library, General Atomics, USA

Plasma Physics Group, Fusion Energy Research Program, University of California at San Diego, USA

Plasma Physics Library, Columbia University, USA

Alkesh Punjabi, Center for Fusion Research and Training, Hampton University, USA

Dr. W.M. Stacey, Fusion Research Center, Georgia Institute of Technology, USA

Dr. J ohn Willis, U.S. Department of Energy, Office of Fusion Energy Sciences, USA

Mr. Paul H. Wright, Indianapolis, Indiana, USA 
The Princeton Plasma Physics Laboratory is operated by Princeton University under contract with the U.S. Department of Energy.

\author{
Information Services \\ Princeton Plasma Physics Laboratory \\ P.O. Box 451 \\ Princeton, NJ 08543
}

Phone: 609-243-2750

Fax: 609-243-2751

e-mail: pppl_info@pppl.gov

Internet Address: http://www.pppl.gov 